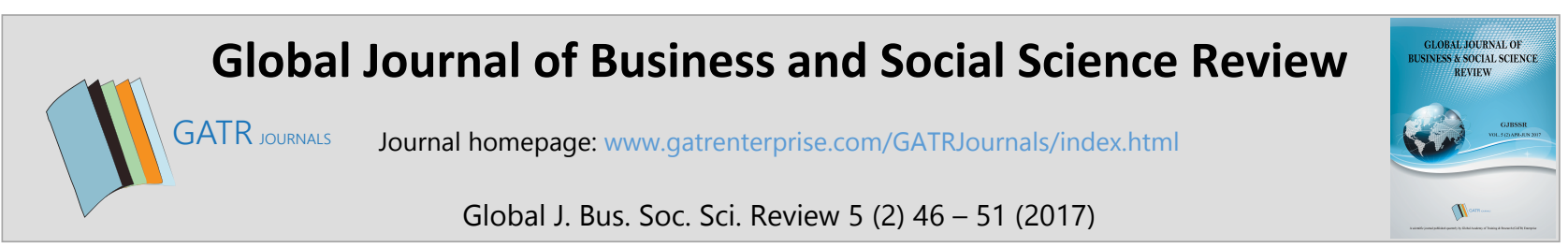

\title{
Are Tourists Willing to Pay for Mitigation of Abrasion? A study on Coastal Areas in Yogyakarta, Indonesia
}

\author{
Evi Gravitiani ${ }^{1 *}$, Mugi Rahardjo ${ }^{2}$ and Norma Sagita Pratiwi ${ }^{3}$ \\ ${ }^{1}$ Magister Economics and Development Studies, Faculty of Economics and Business, Universitas Sebelas Maret, Jl. Ir Sutami, \\ 57126, Surakarta, Indonesia \\ ${ }^{2,3}$ Faculty of Economics and Business, Universitas Sebelas Maret, Jl. Ir Sutami, 57126, Surakarta, Indonesia
}

\begin{abstract}
Objective - Climate change has an impact on not only environmental problems, but also on socio-economic communities. Indonesia as an archipelago country has the second longest coastline after Canada. Indonesia has a high vulnerability to climate change, especially rising sea levels which can cause abrasion. Public awareness is needed to preserve the coastal area, to prevent potential disasters that may occur. Consequently, it is important to analyze the determinant factors of tourist's willingness to pay ('WTP') for mitigation of abrasion and how much it would cost. This study also estimates how the relationship between a tourist's WTP and abrasion on coasts in Yogyakarta.

Methodology/Technique - A multiple linear regression method is used to estimate the determinant factors of a tourist's WTP. The location of this study is on Kuwaru Beach and Pandansimo Beach in Bantul Regency, which have several indicators of the possibility of abrasions. Two hundred respondents were interviewed regarding the influence of socioeconomy and other factors to tourist's WTP.

Findings - That result is equivalent with the level of abrasion for each beach. Variables of education and income have significant effects on tourist' WTP at Kuwaru Beach. While in Pandansimo Beach, age and education have significant effect on WTP. The average tourist's WTP for mitigation in Kuwaru beach and Pandansimo beach at Yogyakarta are Rp $81,150.00$ and $\mathrm{Rp} 62,250.00$.

Novelty - Mitigation on abrasion calls for community awareness amongst local citizens, tourists, and people who conduct business along the beach. For the two beaches studied, the variables used - sex ratio, age, education and income - have a significant effect on a tourists' willingness to pay for abrasion mitigation.

Type of Paper: Empirical.
\end{abstract}

Keywords: Coastal Abrasion; Mitigation; Tourist; Willingness to Pay; Indonesia. JEL Classification: Q25, R11.

\section{Introduction}

Climate change has become an important issue that requires comprehensive examination. Climate change impacts many sectors of human life. For example, with regard to the maritime sector, climate change increases temperature and sea level, the frequency and intensity of extreme weather, changes in precipitation and fresh water runoff that are caused by El-Nino and La-Nina, changes in sea circulation and sea levels. As an

\footnotetext{
* Paper Info: Revised: December 15, 2016

Accepted: April 19, 2017

* Corresponding author:

E-mail: e_gravity2000@yahoo.com

Affiliation: Faculty of Economics and Business, Universitas Seblas Maret, Surakarta, Indonesia
} 
archipelago country with more than 17,000 islands and 80,000 kilometres of coastline, Indonesia is at a high risks of suffering the effects of climate change, especially in relation to rising sea levels which has the potential to drown islands and threaten people who live in coastal area. Research conducted by the Ministry of Maritime and Fishery predicts that the rise of sea levels will increase from year to year and will cause a decline in coastal areas.

Based on research conducted by Numberi et al, 2000, by 2028, Indonesia will experience floods on an annual basis due to rising sea levels. The highest risk is to lowland and coastal areas. Therefore, mitigation management is a very important consideration for people living in coastal areas.

Another consequence of rising sea levels is an increase in the frequency and intensity of fllods, changes in the ocean current and mangrove destruction which could cause abrasion. Coastal area are highly suscptible to climate change, especially those that are densely populated and those that are used for salt mining, fishermen boats backrests, and as tourist attractions.

Coastal abrasion is a significant threat to coastal areas in Indonesia. Data shows that at least $40 \%$ of Indonesia's 80,000 kilometres of coastline has been damaged by abrasion. On average, abrasion has the potential to drown between 2 and 10meters of land per year. Coastal abrasion is caused by two major factors; natural conditions and human activity. Natural factors could be seen by the rise of sea levels due to the effect of global warming. Meanwhile, human activities that might cause abrasion include the erecting of buildings and infrastructure close to the coastline and sand mining, which may potentially damage mangroves that otherwise could have acted as a combatant against big waves.

\section{Literature Review}

\subsection{Climate Change and Abrasion}

Global climate change has a negative impact on coastal ecosystems. Abrasion is one problem that could threaten coastal conditions and may constrict coastlines, damage fishponds and rice field areas, as well as settlements that are located very close to the coast. Abrasion can be defined as coastline constriction from its first or initial position and is predominantly caused by transported sediment from one place to another.

Coastal area damage relates to changes in coastal environment conditions that have a negative impact on human life and other living organisms. Damage to coastal area causes abnormal phenomenon in nature, such as higher perspiration, rising sea levels and tilde waves.

Coastal environments consists of diverse ecosystems. Generally, ecosystems are very complex and rigid toward change. It is possible to say that every activity relating to coastal development and exploration potentially damages ecosystems in coastal areas. Damage in coastal refers to damage to its natural resources. In order to decrease these risks, coastal area development must consider both economics and ecological aspects. Generally, damage to the environment may include pollution, physical degradation, exploitation, coastal abrasion, converting conservation area into settlement, and natural disasters.

\subsection{Mitigation}

Mitigation is a way to decrease the risk of disaster through physical development as well as improvement in facing disaster (UU Article 1 Section 2 Government Regulation No 21/2008). Disaster itself is a progress of events which can disturb social life caused by natural and/or unnatural factors that could result in fatalities, damage to the environment, loss of property and psychological effects.

\subsection{Economics Valuation}

Economics Valuation is a method of measuring natural resource output quantitatively based on market and non-market value. The root of this valuation is the neoclassical economic theory which focuses on consumer 
utility. Based on this neoclassical theory, the individual measurement of goods and services is equal to willingness to pay as supply cost (Samuelson \& Nordhaus, 1990; in Tazkia \& Hayati, 2012).

Willingness to pay is an economic concept used to measure the amount of money that consumers would be likely to pay for the supply of goods and services. According to Altaf, Whittington, Jamal, and Smith (1992), the benefits of consumers' WTP include the ability to estimate future consumers and the ability to quantify feasibility costs. This is an important consideration in the WTP concept since it is necessary to consider both utility and profit.

Factors affected a consumers WTP include their personality characteristics or those of their family members, their ability to pay (Altaf et al. 1993), characteristics of settlement, characteristics of facility and the characteristics of the facility offered.

This research uses the literature review from Saraswaty (2013), Veldhuizena, Tapsuwanb, and Burtonc (2011), Lestari (2014), and Pramastiwi, Irham, Suryantini, and Jamhari (2011). Saraswaty (2013) and Lestari (2014) use willingness to pay on PDAM water supply and improvement of PDAM services. Meanwhile, Veldhuizena et al. (2011) use WTP on drought mitigation management and Pramastiwi et al. (2011) analyses coffee farmers WTP towards environment improvement.

\section{Research Methodology}

This study is conducted in Kuwaru and Pandasimo Beaches, Poncosari Village, Bantul regency, Yogyakarta province. Both of these beaches have reported instances of abrasion quite often compared to other beaches in Bantul regency. This research uses both primary and secondary data. Primary data is collected by conducting interview on tourists at the Kuwaru and Pandansimo Beaches. Secondary data is gathered from the Environment Department, the Tourism Department and the National Board for Disaster Management. The sample size is determined using the Slovin formula with a $90 \%$ level of significance. This research draws from 200 respondents; 100 respondents from each beach.

Multiple linear regression method is used to analyze determinant factors of a tourist's WTP for mitigation of abrasion. Systematically, the model could be written as follows:

$$
\mathrm{Y}=\alpha+\beta_{1 X_{1}}+\beta_{2 X_{2}}+\beta_{3 X_{3}}+\beta_{4 X_{4}}+\beta_{5 X_{5}}+\varepsilon
$$

Where: WTP = Tourists' Willingness to Pay for abrasion mitigation management, X1 = Sex

$\mathrm{X} 2=$ Age

$\mathrm{X} 3=$ Education

$\mathrm{X} 4=$ Mileage

$\mathrm{X} 5=$ Income

Regression analysis in this research is conducted through three repetitions of analysis; regression analysis for the samples from Kuwaru beach, regression analysis for the samples from Pandasimo beach, and regression analysis for the samples from both Kuwaru and Pandasimo beach. Another analysis that is used in this research is WTP, a method used to measure average amount that respondents are able or willing to pay (Walpole in Suprihatiningsih, 2014). Systematically, the model could be written as follows:

$$
\mathrm{EWTP}=\frac{\sum_{i=1}^{n} W i}{n}
$$

Where EWTP = Estimated average Willingness to Pay

$$
\begin{array}{ll}
\mathrm{Wi} & =\text { Value of }-\mathrm{i} \text { WTP } \\
\mathrm{n} & =\text { Total respondents } \\
\mathrm{i} & =-\mathrm{i} \text { respondent }
\end{array}
$$


Climate change contributes to rising sea levels and can lead to abrasion on coastal areas. Mitigation of abrasion needs community awareness including of the tourists who frequently enjoying those areas for recreational purposes. This study estimates tourists' WTP for abrasion mitigation management and the determinant factors of such. The research frame is shown on figure 1.

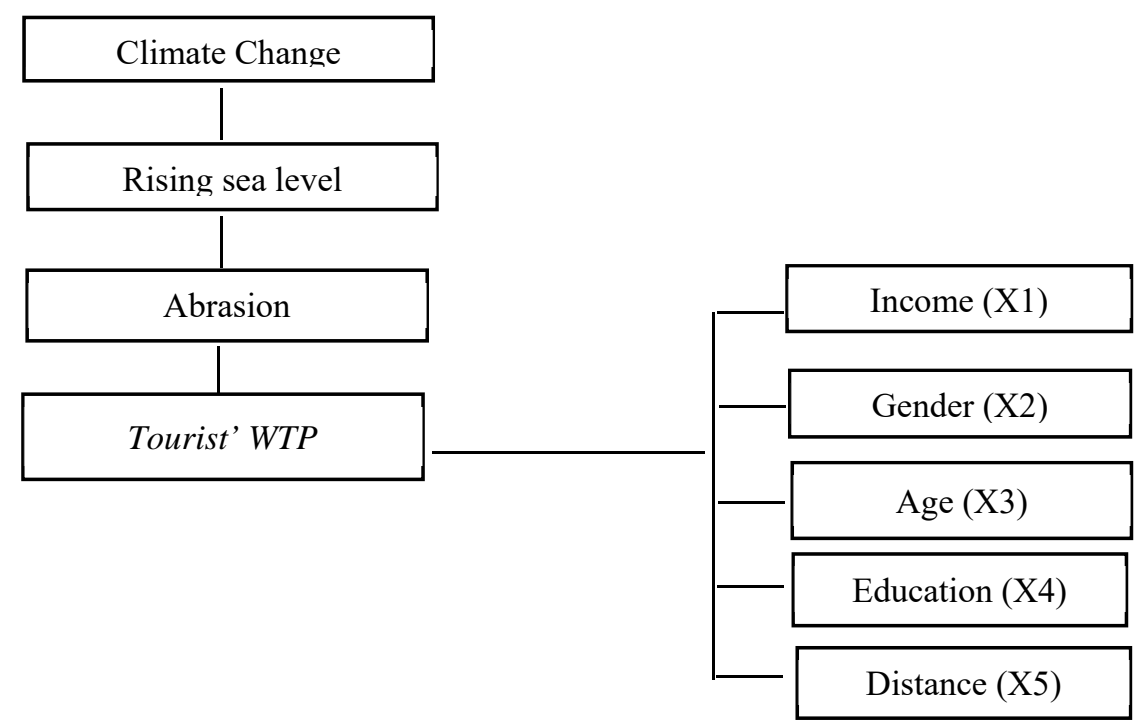

Figure 1. Research Framework

\section{Results}

The estimated result of the relationship between socio-economic factors, sepecifically tourists' sex, education, mileage and income, on their willingness to pay for abrasion mitigation management could be explained as follows:

Table 1. Multi linear Regression Analysis using Ordinary Least Square (OLS)

\begin{tabular}{|l|l|l|l|l|}
\hline \multicolumn{2}{|c|}{ No } & \multirow{2}{*}{ Variables } & Obtained Value B \\
\cline { 3 - 5 } & & Kuwaru & Pandansimo & $\begin{array}{l}\text { Kuwaru } \\
\text { Pandansimo }\end{array}$ \\
\hline 1 & Constant & 2.127 & -1.314 & 1.437 \\
\hline 2 & dummy_sex & 0.187 & 0.086 & 0.131 \\
\hline 3 & Age & -0.182 & -0.183 & -0.200 \\
\hline 4 & Education & 0.280 & 0.438 & 0.360 \\
\hline 5 & Mileage & 0.044 & 0.164 & 0.066 \\
\hline 6 & Income & 0.258 & 0.121 & 0.233 \\
\hline 7 & dummy_beach & & & 0.068 \\
\hline
\end{tabular}

Based on the output above, the obtained regression equations are as follows:

$$
\begin{aligned}
& \text { WTP }_{\text {Kuwaru }}=2.127+0.187_{X_{1}}-0.182_{X_{2}}+0.280_{X_{3}}+0.044_{X_{4}}+0.258_{X_{5}}+\varepsilon \\
& \text { WTP }_{\text {Pdnsmo }}=-1.314+0.086_{X_{1}}-0.183_{X_{2}}+0.438_{X_{3}}+0.164_{X_{4}}+0.121_{X_{5}}+\varepsilon
\end{aligned}
$$


$\mathrm{WTP}_{\text {kuwaruandpandansimo }}=1.437+0.131_{X_{1}}-0.200_{X_{2}}+0.360_{X_{3}}+0.066_{X_{4}}+0.233_{X_{5}}+0.068_{X_{6}}+\varepsilon$

The results of the F-test level are 5.300 for Kuwaru Beach, 12.069 for Pandansimo Beach and 13.499 for both of Kuwaru and Pandansimo. They are all at a significance level of 0.05 and the probability value is less than 0.05 . It is concluded that the independent variable - in this case sex, age, education, mileage and income - affect tourists' WTP to mitigate abrasion.

Table 2. F-Test

\begin{tabular}{|l|l|l|l|l|l|l|l|}
\hline \multicolumn{2}{|c|}{ Coefficients $^{\mathbf{a}}$} \\
\hline \multirow{2}{*}{ No } & \multirow{2}{*}{ Variables } & \multicolumn{2}{l|}{ Kuwaru } & \multicolumn{2}{l|}{ Pandansimo } & \multicolumn{2}{l|}{$\begin{array}{l}\text { Kuwaru and } \\
\text { Pandansimo }\end{array}$} \\
\cline { 3 - 9 } & & T & sig. & T & sig. & T & sig. \\
\hline 1 & Constant & 1.006 & 0.317 & 0.748 & 0.456 & 0.837 & 0.404 \\
\hline 2 & dummy_sex & 1.979 & 0.051 & 1.047 & 0.298 & 2.124 & 0.035 \\
\hline 3 & Age & -1.822 & 0.072 & -2.007 & 0.048 & -3.093 & 0.002 \\
\hline 4 & Education & 2.951 & 0.004 & 4.368 & 0.000 & 5.652 & 0.000 \\
\hline 5 & Mileage & 0.475 & 0.636 & 1.914 & 0.059 & 1.073 & 0.285 \\
\hline 6 & Income & 2.535 & 0.013 & 1.158 & 0.250 & 3.204 & 0.002 \\
\hline 7 & dummy_beach & & & & & -1.043 & 0.298 \\
\hline
\end{tabular}

Source: Data estimates, 2017

The T-test denotes significance at the 0.05 level. In Kuwaru, the variables of education and income are found to significantly influence a tourists' WTP. Both variables have a probability value of less than 0.05 , 0.004 and 0.013 respectively, while the variables of sex, age, and mileage do not significantly affect tourists' WTP, with probability value of more than 0.05 . In Pandansimo, the variables of age and education significantly influence tourists' WTP with a probability value of 0.048 and 0.000 respectively. Whereas sex, mileage, and income do not significantly affect tourists' WTP. In both of the two beaches, the variables of sex, age, education, and income significantly affect tourists' WTP simultaneously. Those variables have a probability value of less than 0.05 , being $0.035,0.002,0.000$ and 0.002 respectively. Mileage and beach location were not found to significantly affect a tourists' WTP.

The determinant coefficient value obtained from this test is equal to 0.178 in the test of samples from Kuwaru Beach meaning that $17.8 \%$ of the variations in WTP are caused by differences in sex, age, education, mileage and income. The remaining $82.2 \%$ is explained by other variables outside the model used.

The adjusted $\mathrm{R}$ square value in Pandansimo is 0.359 demonstrating that $35.9 \%$ of the variations in WTP are caused by differences in sex, age, education, mileage and income, while the remaining $64.1 \%$ are explained by other variables outside the model used. Furthermore, the adjusted R square value of the simultaneous test with the samples from both Pandansimo and Kuwaru Beach indicates a value of 0.274 showing that $27.4 \%$ of the variations in WTP can be explained by the independent variables; sex, age, education, mileage and income. The remaining $77.6 \%$ is explained by other variables outside the model used. The greatest value of $\mathrm{R}^{2}$ is $35.9 \%$ for Pandansimo, $17.6 \%$ for Kuwaru and $27.4 \%$ for the two beaches combined.

\section{Conclusion}

Education and income have a significant effect on a tourists' WTP in Kuwaru. While the variables of sex, age and mileage have no significant effect on tourists' WTP. In Pandansimo, variables of age and education have a significant effect on tourists' WTP however sex, mileage and income have no significant effect.

Education and income have significant effect on tourist's WTP at both of the two beaches while sex, mileage and beach location have no effect. 
The average of a tourist' WTP in Kuwaru Beach and Pandansimo Beach is between Rp 81,150 to Rp 65,250 respectively. This data allows us to conclude that the value of a tourists' WTP is equivalent to the level of abrasion that occurs at the beach.

\section{References}

Altaf, M. A., Whittington, D., Jamal, H., \& Smith, V. K. (1993). Rethinking rural water supply policy in the Punjab, Pakistan. Water Resources Research, 29(7), 1943-1954.

Lestari, S. (2014). Analisis Willingness To Pay Masyarakat Terhadap Peningkatan Pelayanan PDAM Di Jalan Danau Sentarum Dan Sekitarnya. [Analysis of Willingness To Pay Society Against Improving PDAM Service On Jalan Danau Sentarum and Surrounding]. Jurnal Mahasiswa Teknik Lingkungan Untan, 1(1).

Munawaroh, S., Wibisono, H., \& Immanuela, I. (2014). Faktor-Faktor Yang Mempengaruhi Kemauan Untuk Membayar Pajak Wajib Pajak Orang Pribadi Yang Melakukan Pekerjaan Bebas. [Factors Affecting the Willingness to Pay Taxes Individual Taxpayers Who Do Free Work] Jurnal Riset Manajemen dan Akuntansi, 2(1), 35-44.

Pramastiwi, F. E., Irham, I., Suryantini, A., \& Jamhari, J. (2011). Kesediaan Membayar Petani Kopi Untuk Perbaikan Lingkungan. [Willingness to Pay Coffee Farmers for Environmental Improvement] Jurnal Ekonomi Pembangunan: Kajian Masalah Ekonomi dan Pembangunan, 12(2), 187-199.

Ratih Putri, R. (2014). Indikator Adaptasi Masyarakat Terhadap Krisis Air (Studi Kasus Di Palu'e, Ntt Dan Kembangbahu, Jawa Timur). [Indicator of Community Adaptation to Water Crisis (Case Study In Palu'e, NTT And Kembangbahu, East Java)] Jurnal Sosek Pekerjaan Umum, 6(1).

Ridwan, R., \& Chazanah, N. (2013). Penanganan Dampak Perubahan Iklim Global pada Bidang Perkeretaapian Melalui Pendekatan Mitigasi dan Adaptasi. [Handling the Impacts of Global Climate Change on Railways through Mitigation and Adaptation Approaches.] Jurnal Teknik Sipil, 20(2), 113-142.

Samuelson, Paul A., and William D. Nordhaus . (1990). Economics (14th ed.). New York: McGraw-Hill.

Saraswaty, A. N. (2013). Kesediaan Membayar Pelanggan Rumah Tangga Untuk Pelayanan Aair Bersih dari PDAM di Kabupaten Badung.[ Willingness to Pay Household Customers For Water Services from PDAM in Badung Regency] E-Jurnal Ekonomi Pembangunan Universitas Udayana, 2(10).

Supit, N. L., Kumenaung, A. G., \& Tumilaar, R. L. (2015). Analisis Faktor-Faktor Yang Mempengaruhi Penerimaan Pajak Hotel Di Kota Manado. [Analysis of Factors Affecting Hotel Tax Receipts In Manado City] Jurnal Berkala Ilmiah Efisiensi, 15(3).

Suprihatiningsih, S. (2014). Penalaran Matematis Siswa Dalam Pemecahan Masalah Pada Materi Pokok Faktorisasi Bentuk Aljabar Di Kelas Viii Smp Negeri 1 Surakarta [Student Mathematical Reasoning In Problem Solving On Main Material Factor Formation Algebra In Class Viii Smp Negeri 1 Surakarta] (Doctoral dissertation), UNS, Sebelas Maret University, Indonesia.

Tazkia, F. O., \& Hayati, B. (2012). Analisis Permintaan Obyek Wisata Pemandian Air Panas Kalianget, Kabupaten Wonosobo Dengan Pendekatan Travel Cost [Request Analysis Of Tourism Objects Of Water Hot Warming Kalianget, Wonosobo Regency With Travel Cost Approach] (Doctoral dissertation), Fakultas Ekonomika dan Bisnis, Universitas Diponegoro, Indonesia.

Undang-Undang Republik Indonesia [Law of the Republic of Indonesia] No 24 Tahun 2007 Tentang Penanggulangan Bencana [About Disaster Management]

Veldhuizena, L. J. L., Tapsuwanb, S., \& Burtonc, M. (2011). Adapting to climate change: Are people willing to pay or change?. In Conference Proceedings (pp. 3003-3009).

Yuliarmi, N. N., \& Riyasa, P. (2007). Analisis faktor-faktor yang mempengaruhi kepuasan pelanggan terhadap pelayanan PDAM Kota Denpasar. [Analysis of factors that affect customer satisfaction on service PDAM Denpasar] Buletin Studi Ekonomi, 12(1), 9-28. 